\title{
The Formation of Regional Financial Center in China: Based on the City of Guangzhou
}

\author{
Ying Zeng \\ Department of Finance, College of Economics, Jinan University, Guangzhou, China \\ Email:949656905@qq.com
}

Received 1 April 2016; accepted 26 April 2016; published 29 April 2016

Copyright @ 2016 by author and Scientific Research Publishing Inc.

This work is licensed under the Creative Commons Attribution International License (CC BY). http://creativecommons.org/licenses/by/4.0/

(c) (i) Open Access

\begin{abstract}
This paper sets up an Evaluation Index System of the regional financial center with variable selected from three dimensions: economic development, financial development degree and innovation environment support. The principal component analysis methodology is then used to evaluate competition of six cities including Guangzhou. According to the composite score, Guangzhou is ranked fourth, behind Beijing, Shanghai and Shenzhen. In addition, the SWOT analysis of Guangzhou regional financial center is adopted and two major problems are pointed out respectively, headquarter economy in low level and small financial scale. Finally, four recommendations to improve regional financial center of Guangzhou are put forward.
\end{abstract}

\section{Keywords}

Regional Financial Center, Evaluation Index System, Principal Component Analysis, SWOT Analysis

\section{Introduction}

World-famous international financial centers are determined by the combined effects of natural factors, economic factors as well as human factors, which play an important role in gathering capitals, optimizing the allocation of financial resources and promoting the development of finance. It is obvious that financial center stands in an important strategic position. For China, when it is in the economy period of the high-speed development, the huge demand for funds requires financial centers to manage and allocate the financial resources effectively. But when it comes to the China's New Normal, structure transformation and development of economy can't do without the support of finance objectively. In modern economy era, the core status of finance is more and more obvious. Therefore, the financial development will greatly drive the national economy to break through the bottleneck it trapped in. On the other hand, the regional financial center not only gathers the financial resources of the region, but also has long-term significance of boosting the surrounding areas. The upsurge of construction of 
regional financial centers never slows down. In China, more than 30 cities have already brought up the construction of regional financial centers. Beijing, the national financial center, performs its function of national financial operator. Shanghai makes efforts to build up an international financial center and to enhance its financial clout constantly. Shenyang, Tianjin, Zhengzhou, Hangzhou, Wuhan, Chengdu and other cities try their best to catch up with the developing cities on the path of building up regional financial centers. As one of the first-tier cities of China and the large central cities in southern China, the forming of regional financial center by Guangzhou meets the needs of economic development, and is of great significance for the economic prosperity of the "Pan-Pearl River Delta" region.

Since Guangzhou has set up the goal of constructing a regional financial center, its finance industry has made great development. However, in terms of the finance industry scale and strength, there is still a gap between Guangzhou and other financial centers that are more mature such as Beijing, Shanghai and Shenzhen. This paper aims to make a comparison of six cities in China to explore the issues and weaknesses of Guangzhou Regional Financial Center and to make suggestions to overcome the hardships above.

The rest of this paper proceeds as follows. Section 2 briefly reviews the relevant literature. Section 3 describes the data and variables used in the paper. Section 4 presents the results of principal component analysis. Section 5 carries on with SWOT analysis and Section 6 concludes and puts forward recommendations.

\section{Related Literature}

Studies in the early period are mainly theoretical. Kindleberger (1974) assumed that regional financial center is a place that gathers financial institutions and plays a role of transaction intermediary [1]. Thrift (1994) considered the most important function of regional financial center is to generate, obtain, interpret and spread financial information [2]. Porteous (1995) deemed the regional financial center has top function of providing high-end financial products for the region, its hinterland and even the world [3]. Denis (2002) suggested that regional financial center was a core area, where financial institutions are highly aggregated, the capital market is developed as well as trading thrives [4]. Chinese scholars have also made certain researches, Wang R.X. and Shi D. (2005) pointed out the regional financial center is the hub of financing [5]. Xie T.F. (2008) emphasized that the nature of a financial center is agglomerating and optimizing the allocation of financial resources effectively, which will do help to reduce transaction risk and improve transaction efficiency [6]. Based on the above references, it can be concluded that regional financial center is a core zone with the financial resources highly concentrated, in which the capital market has developed into a high level with active market transaction and certain radiation impact on the hinterland.

As for how to measure the development level of regional financial center, Reed (1981) analyzed nine financial variables in 76 cities around the world by using Cluster Analysis and divided financial center into five grades: provincial and municipal, sub-national, national, regional and international [7]. Richard et al. (1990) believed that, location cost and advantages, labor and human resources, communication and information technology, legislation and taxes, these four elements must be taken into account when evaluating the competition of a financial center [8]. In order to build the Evaluation Index System, Zhou L.Q. and Pan H.S. (2003) selected 29 indicators from the following five dimensions: comprehensive economic strength, financial strength, financial institutions development degree, direct financing strength and financial position [9]. Sun J. and Miao J.J. (2006) took 43 sample areas as research object, using principal component analysis to build potential index system for financial center, and proposed four models of regional financial center formation in China based on potential scores [10]. Xie F.Y. (2013) assessed finance industry agglomeration of Henan Province by operating Wilson model and using component factor analysis by picking up variables from three aspects: overall and sub-sector status of finance, regional distribution of financial resources [11]. Therefore, it can be seen that the Financial Center Evaluation System provides a way to estimate the financial competitiveness of different areas, while there is no uniform standard for indicator selection.

For the sake of achieving the target, socialists from all walks of life make great efforts to explore the best mode of regional financial center construction. Lu L. (2009) pointed out that Guangzhou and Shenzhen have to play emphasis on financial innovation [12]. Shao X.Y. and Zhu Z.Y. (2010) applied urban flow model to analyze the financial agglomeration and positive spillover effects to adjacent areas in Guangdong Province, and proposed the conception of building "Dual-core Regional Financial Center" between Guangzhou and Shenzhen [13]. Lu M.F. and Pan X.H. (2010), Tao Y. (2011) stated briefly the lack of coordinated project, redundant con- 
struction, blind competition and over-reliance on government are the major problems during the process of regional financial center construction [14] [15]. Chen Y. and Zhu Y.Z. (2011) held the viewpoint that the regional financial center not only needs to gather a large number of financial institutions, but it also needs to improve the connection mechanism to achieve coordinated development [16]. Li J.C. and Zhou Q.Q. (2013) underlined the necessity and importance for Guangzhou and Shenzhen to build up the regional financial center together by making a qualitative analysis; furthermore, they made exploration about the construction model [17].

To sum up, scholars have already made beneficial exploration about the connotation of the regional financial center and how to construct it. However, the existing researches lack depth study about the city of Guangzhou. In this paper, we apply the Financial Center Evaluation System to make a comparative analysis of six domestic cities with the higher financial development level for the first time. In addition, we focus on looking for the advantages and disadvantages in all aspects of formation of the regional financial center for Guangzhou and then provide some significant suggestions.

\section{Variable Analysis}

Before introducing the empirical model, a specification is made on the data used to create the Regional Financial Center Evaluation Index System. As far as we are concerned, the influencing factors of a regional financial center mainly include three aspects: economic development level, financial development degree, innovation environment support.

Firstly, economic development level of the city is a prerequisite for regional financial center and the material support of its acquired growth as well. The economic strength is shown by national economy, government revenues, citizen's income level and other aspects and thus four indicators are chosen: per-capita GDP, per-capita revenue, per-capita disposable income of urban households and total fixed asset investment. In addition, we also examine the impact of urban economic structure through tertiary industry contribution rate and actual use of foreign direct investment. Secondly, the urban financial development degree can be measured by financial scale, financial efficiency, market financing capacity and market opening up degree. Generally speaking, scale effect and financial competitiveness will enhance with the increase of financial scale, thus we select two indicators: financial interrelations' ratio and value added of financial intermediation. Wang Z.Q. and Sun G. (2003) used indicator financial efficiency to examine financial intermediaries' capacity of translating savings into investments [18]. Marketing financing capacity can be reflected by the capital market trading activeness, which reveals through the number of stock accounts, security transactions and total market capitalization. Financial openness, on the one hand, can directly attract foreign investment, and bring in, on the other hand, technology and institution resources to promote financial development. Therefore, finance openness plays a vital role in financial center. Based on the data available, this paper chooses foreign currency deposits accounted for ratio and the number of foreign banks to measure the degree of financial opening up. Finally, innovation environment support is crucial during the process of financial center formation. From the perspective of personnel training and scientific research, we pick out five variables to measure this indicator, including the number of institutions of higher learning, the number of postgraduate, the number of R\&D Institute, the number of $R \& D$ personnel, $R \& D$ Intramural expenditure and the number of patents granted. All the indicators mentioned above are listed in Table 1.

\section{Principal Component Analysis}

Many factors have an impact on the competitiveness of a regional financial center, so we use principal component analysis to find out the major determinations. Strong correlation variables attribute to a component, and all these new components can describe information reflected by the observed variables. Standardization of data is operated by SPSS 19.0 statistical software. The number of component is determined based on variance contribution rate and cumulative variance contribution rate. Then we calculate the score of each component and the composite scores of each city. On the basis of the composite scores, we determine the rankings of the objects' financial competitiveness.

Table 2 reports the variance contribution rate and the cumulative variance contribution rate from principal component analysis. Four components' eigenvalue are higher than 1, however, the cumulative contribution rate of the first three factors is $91.129 \%$, suggesting that the three components are able to explain the most part of information of the original data. In addition, the correlation between these three factors is weak and the information overlapped rate is low. It is reasonable to choose the three components as indicators of financial center's 
Table 1. Variables description.

\begin{tabular}{|c|c|c|c|c|}
\hline Level-one indicators & Secondary indicators & Variables & Symbol & Description \\
\hline \multirow{6}{*}{$\begin{array}{l}\text { Economic development } \\
\text { level }\end{array}$} & \multirow{4}{*}{ Economic strength } & PCG & $\mathrm{X} 1$ & Per-capita GDP, Unit: RMB 1 Yuan \\
\hline & & PCR & $\mathrm{X} 2$ & Per-capita revenue, Unit: RMB 1 Yuan \\
\hline & & PCDI & X3 & $\begin{array}{l}\text { Per-capita disposable income of urban } \\
\text { households, Unit: RMB } 1 \text { Yuan }\end{array}$ \\
\hline & & TFAI & $\mathrm{X} 4$ & $\begin{array}{l}\text { Total fixed asset investment, Unit: RMB } 100 \\
\text { million Yuan }\end{array}$ \\
\hline & \multirow[b]{2}{*}{ Economic structure } & TICR & X5 & Tertiary industry contribution rate (\%) \\
\hline & & AFDI & X6 & $\begin{array}{l}\text { Actual use of foreign direct investment, Unit: } \\
\text { USD } 10 \text { thousand }\end{array}$ \\
\hline \multirow{3}{*}{$\begin{array}{l}\text { Financial development } \\
\text { degree }\end{array}$} & \multirow{2}{*}{ Financial scale } & FIR & X7 & $\begin{array}{l}\text { Financial interrelations ratio (\%) is equal to } \\
\text { the total financial scale divided by the local } \\
\text { GDP }\end{array}$ \\
\hline & & VAFI & $\mathrm{X} 8$ & $\begin{array}{l}\text { Value added of financial intermediation, Unit: } \\
\text { RMB } 100 \text { million Yuan }\end{array}$ \\
\hline & \multirow[t]{2}{*}{$\begin{array}{l}\text { Financial development } \\
\text { efficiency }\end{array}$} & $\mathrm{FE}$ & X9 & $\begin{array}{l}\text { Financial efficiency is equal to the financial } \\
\text { institutions deposits divided by the financial } \\
\text { institutions loans }\end{array}$ \\
\hline \multirow{5}{*}{$\begin{array}{l}\text { Financial development } \\
\text { degree }\end{array}$} & & SA & $\mathrm{X} 10$ & Number of stock accounts \\
\hline & \multirow[t]{2}{*}{$\begin{array}{l}\text { Market financing } \\
\text { capacity }\end{array}$} & ST & $\mathrm{X} 11$ & $\begin{array}{l}\text { Security transactions, Unit: RMB } 100 \text { million } \\
\text { Yuan }\end{array}$ \\
\hline & & TMC & $\mathrm{X} 12$ & $\begin{array}{l}\text { Total market capitalization, Unit: RMB } 100 \\
\text { million Yuan }\end{array}$ \\
\hline & \multirow{2}{*}{$\begin{array}{l}\text { Financial opening up } \\
\text { degree }\end{array}$} & FCDR & $\mathrm{X} 13$ & $\begin{array}{l}\text { Foreign-currency deposits accounted for ratio } \\
\text { (\%) }\end{array}$ \\
\hline & & FB & $\mathrm{X} 14$ & Number of foreign banks \\
\hline \multirow{6}{*}{$\begin{array}{l}\text { Innovation environment } \\
\text { support }\end{array}$} & \multirow{2}{*}{ Personnel training } & IHL & $\mathrm{X} 15$ & Number of institutions of higher learning \\
\hline & & NP & $\mathrm{X} 16$ & Number of postgraduates \\
\hline & \multirow{4}{*}{ Scientific research } & RDI & $\mathrm{X} 1$ & Number of R\&D Institutes \\
\hline & & $\mathrm{RDP}$ & $\mathrm{X} 18$ & Number of R\&D personnel \\
\hline & & $\mathrm{RDE}$ & X19 & $\begin{array}{l}\text { R\&D Intramural expenditure, Unit: RMB } 100 \\
\text { million Yuan }\end{array}$ \\
\hline & & PG & X20 & Number of patents granted \\
\hline
\end{tabular}

Note: The data used is of 2014. Source of data: The data of three dimensions are selected from each city's Statistical Yearbook in 2015, which can download on the official website for Branch of the National Bureau of Statistics. Respectively, the URLs for the branches are http://www.bjstats.gov.cn/; http://www.stats-sh.gov.cn/; http://www.sz.gov.cn/; http://www.gzstats.gov.cn/; http://www.stats-tj.gov.cn/; http://www.whtj.gov.cn/.

Table 2. Total variance explained.

\begin{tabular}{ccccccc}
\hline & \multicolumn{3}{c}{ Initial Eigen values } & \multicolumn{3}{c|}{ Extraction sums of squared loadings } \\
\hline Component & Total & \% of Variance & Cumulative \% & Total & \% of Variance & Cumulative \% \\
\hline 1 & 9.512 & 47.562 & 47.562 & 9.512 & 47.562 & 47.562 \\
2 & 5.010 & 25.050 & 72.612 & 5.010 & 25.050 & 72.612 \\
3 & 3.703 & 18.517 & 91.129 & 3.703 & 18.517 & 91.129 \\
4 & 1.108 & 5.539 & 96.667 & & & \\
5 & 0.667 & 3.333 & 100.000 & & & \\
\hline
\end{tabular}

Extraction Method: Principal Component Analysis. Note: the first five components' cumulative contribution rate is $100 \%$, so just this part of the results is listed. 
competitiveness for they are able to fully reflect the variable conditions. To be specific, we view component 1 as "Financial Development Component", because it contains larger load value on the variables: FIR, VAFI, FE, SA, ST, TMC, FCDR and FB. Component 1, an important affecting factor with the contribution rate of $47.562 \%$, reflects the financial scale, financial efficiency, market financing capacity as well as the degree of finance opening up. Component 2, with larger load value on variables PCR, TICR and AFDI, is defined as "Economic Development Component" with the contribution rate of $25.050 \%$. The component reflects the level of economic development of the city. Component 3 is labeled as "Innovative Environmental Component" with the contribution rate of $18.517 \%$, whose load value shows higher weight on variables IHL, NP, RDP and RDE.

According to the component score coefficient matrix, we calculate the score of each component and represented, which are marked as $F_{1}, F_{2}$ and $F_{3}$. Composite score $F=0.5219 F_{1}+0.2749 F_{2}+0.2032 F_{3}$, and the coefficient equal to its variance contribution rate divided by cumulative variance contribution rate of the three components.

Table 3 lists the component score and ranking. From the perspective of the "Financial Development Component", Shanghai, whose financial interrelations ratio is $60.69 \%$, obtains the highest score with no doubt, indicating that its finance development is relatively perfect. Guangzhou's score is -0.235 and ranked No. 4, we can say that a large gap exists between Guangzhou and the developed domestic regional financial centers. When it comes to the "Economic Development Component", Beijing, as the capital and political, economic, cultural center of China, topped the chart. Guangzhou ranked No. 3, we suppose that economic development of Guangzhou provides strong support for its finance construction to some extent. In accordance with Guangzhou's composite score and ranking, it is far behind Beijing, Shanghai and Shenzhen. In the future, Guangzhou has to transform pressure into motivation and makes great efforts to shrink the gap.

\section{SW0T Analysis}

In this section, we carry out an SWOT analysis for Guangzhou on the formation of the regional financial center.

\subsection{Strength}

\subsubsection{Location Advantage}

Guangzhou, located in the hinterland of southern China and the middle of the Pearl River Delta Economic Zone, is a bridge that connects the economy of east and west wings. As the economic, political and cultural center of Guangdong Province, Guangzhou can obtain political franchise value. Moreover, Guangzhou, used to be one port of the Maritime Silk Route, is an important trading port since ancient times. It can not only affect the large areas of the Pearl River Basin, but also explore the international market. In addition, Guangzhou can take great advantage of the adjacent to Hong Kong to learn successful experience about formation of an international financial center and to bring in financial technology and personnel.

\subsubsection{Transportation Advantage}

As an international metropolis, Guangzhou is famous for the complete transportation infrastructure and it is the hub of land, sea and air communications in southern China. Specifically, as for the local transportation, there are nine routes of Guangzhou Metro that are operating as of December 28th, 2013. Subway has become the main way of transportation for citizens and the average daily passenger flow volume has reached 6.234 million by March 2014. The port transport and cargo throughput of the PORT OF GUANGZHOU in 2014 has reached $482,172,500$ tons, which is 2.16 times of that of the PORT OF SHENZHEN, accounting for $62.48 \%$ of the whole province and ranked third in China. The PORT OF GUANGZHOU has become the material distribution center and the largest international trade port in southern China. In civil aviation transport, Baiyun International Airport is of great importance for domestic air transportation, for its passenger throughput has grown up to 54.79 million in 2014 , accounting for $56.07 \%$ of the whole province and $14.05 \%$ of the country; while its total cargo throughput is 1.8963 million tons, accounting for $31.96 \%$ of the country. The developed transportation net promotes the economic development of Guangzhou and provides hardware support for construction of a regional financial center.

\subsubsection{Financial Agglomeration Advantages}

Financial agglomeration is the most important basis for the formation of a regional financial center. We can say 
Table 3. Component score and ranking.

\begin{tabular}{cccccccccc}
\hline City & $F_{1}$ & Rank & $F_{2}$ & Rank & $F_{3}$ & Rank & $F$ & Rank \\
\hline Beijing & 4.810 & 2 & 2.992 & 3 & 1.603 & 1 & 3.650 & 2 \\
Shanghai & 10.592 & 1 & 2.037 & 1 & -1.267 & 6 & 5.825 & 1 \\
Guangzhou & -0.235 & 4 & 1.912 & 2 & 0.986 & 3 & 0.598 & 4 \\
Shenzhen & 3.377 & 3 & 0.650 & 4 & 1.054 & 2 & 2.154 & 3 \\
Tianjin & -0.830 & 5 & -0.526 & 6 & -0.471 & 5 & -0.672 & 5 \\
Wuhan & -0.960 & 6 & -0.480 & 5 & -0.506 & 4 & -0.735 & 6 \\
\hline
\end{tabular}

Note: Component score is calculated based on component score coefficient matrix.

that financial agglomeration effect of Guangzhou appears gradually. Currently, Guangzhou contains many types of financial institutions, to be specific, twenty-two foreign bank representative offices, three security companies, eight futures brokerage companies, three fund companies, four assets and equity exchanges have settled down in Guangzhou. CBD has been built up in Zhujiang New Town, which undertakes the responsibility to attract more and more headquarters and branch offices of financial institutions. Moreover, location quotient of Guangzhou financial industry is higher than 1, suggesting that the financial agglomeration effect of Guangzhou is good and is better than the provincial average.

\subsubsection{FTZ Advantage}

Guangzhou Nansha Free Trade Zone aims to become the bridge that connects Hong Kong and Macao, with a hope to attract more investors from the two areas. GDP of Nansha District went up to 101.635 billion yuan in 2014, of which the tertiary industry was 20.764 billion yuan with an increase of $11.3 \%$. Industrial output value was 276.888 billion yuan, of which the output value of foreign-invested enterprises increased by $16.1 \%$, accounting for $51.55 \%$ of the above-scale industrial output value over the region. Particularly worth mentioning is the fact that the output of enterprises from Hong Kong, Macao and Taiwan increased 15.5\%, accounting for $27.65 \%$ of the above-scale industrial output value of the region. The actual utilization of foreign investment amounted to 1.0038 billion dollars with an increase of $4.99 \%$. The preferential taxation policy and other politic dividend of the FTZ will attract more foreign companies. It is undoubted that the FTZ will create more opportunities for promoting the development of finance.

\subsection{Weakness}

\subsubsection{Low Level of Headquarters Economy}

From the perspective of structure, the formation of a financial center is similar to the headquarters economy. That is, a region makes full use of its resource advantages to attract and gather a great number of groups, and then form reasonable division of a value chain through polarization effect and diffusion effect, thus realizes the target of promoting the development of region economy. The economy strength and market position for a city can be revealed completely by the number of headquarters settled in. From Table 4, it is obvious that the headquarters in Guangzhou are far smaller than they are in the other three cities. That's because the attraction in the aspect of making introduction of enterprise headquarters and elites for Guangzhou is too weak. It is urgent for Guangzhou to enhance the comprehensive carrying capacity.

From Table 5, there are altogether twenty financial institutions headquartered in Guangzhou. This figure is far lower than that of Beijing, Shanghai and Shenzhen. It indicates that the lack of headquarters and weak impact of headquarter is a serious problem in the process of building up a regional financial center for Guangzhou. This issue will undoubtedly become a surge resistance, which may cause butterfly effect in the financial system. The adverse impact may weaken the radiation effect of Guangzhou performs on surrounding cities and it is too difficult for Guangzhou to attract and retain financial elites, restricting its financial innovation and development.

\subsubsection{Small Financial Scale}

According to the data in Table 6, securities transactions and securitization degree of Guangzhou are at the bottom of the list of the four cities, indicating that the stock market hasn't play a proper role of financing and it needs to be improved urgently. The difference between the deposits and loans of financial institutions reflects 
the scale and capacity of financing market. That is, the greater the value, the weaker its financing capability. Guangzhou has a comparatively small balance of 11,237,580 million yuan, indicating its relatively strong capability of financing, which offers certain possibilities for the construction of region financial center.

Table 7 reflects the change of Guangzhou's financial industry. The financial contribution to GDP took on a growth trend from 2008 to 2014, but the value just was $8.51 \%$ in 2014, compared to the rate of $14.43 \%$ in Shanghai. Financial contributions to tertiary industry and to GDP are increasing but relatively slow. It is easy to come to the conclusion that financial scale of Guangzhou is small and the development level is low. Therefore, there is a big room for improvement and financial contributions have to be enhanced.

Table 4. The number of China's top 500 enterprises and listed companies ${ }^{a}$.

\begin{tabular}{ccccc}
\hline & Beijing & Shanghai & Shenzhen & Guangzhou \\
\hline China’s top 500 enterprises & 98 & 43 & 32 & 12 \\
Listed companies & 235 & 206 & 191 & 206 \\
\hline
\end{tabular}

a: The data is about the number of China's top 500 enterprises and listed company headquartered in these cities by 2014. Source of data: The same as Table 1.

Table 5. The number of financial institution ${ }^{\mathrm{a}}$.

\begin{tabular}{ccccc}
\hline & Beijing & Shanghai & Shenzhen & Guangzhou \\
\hline Bank & 15 & 4 & 6 & 3 \\
Security & 18 & 22 & 19 & 3 \\
Fund company & 23 & 45 & 20 & 3 \\
Futures commission merchants & 19 & 28 & 6 & 8 \\
Insurance company & 7 & 3 & 64 & 20 \\
Total & 82 & 102 & 6
\end{tabular}

${ }^{\mathrm{a}}$ : Data is and about the number of financial institution headquartered in these cities by 2014. Source of data: We make a count to the above institution according to the agencies released on the website of China Securities Regulatory Commission, China Banking Regulatory Commission, China Insurance Regulatory Commission.

Table 6. The financial scale ${ }^{a}$.

\begin{tabular}{ccccc}
\hline & Beijing & Shanghai & Shenzhen & Guangzhou \\
\hline Domestic and foreign currency deposits of financial institutions & $100,095.50$ & $73,882.45$ & $59,259.04$ & $35,469.29$ \\
Domestic and foreign currency loans of financial institutions & $53,650.60$ & $47,915.81$ & $31,984.07$ & $24,231.71$ \\
Premium income & 1207.20 & 986.75 & 548.66 & 601.81 \\
Securities transactions & $232,318.56$ & $1,281,498.00$ & $444,708.19$ & $49,514.63$ \\
Insurance penetration & 0.06 & 0.04 & 0.03 & 0.04 \\
Securitization degree & 10.89 & 54.38 & 27.79 & 2.97 \\
\hline
\end{tabular}

${ }^{\mathrm{a}}$ : Data is up to 2014. Unit: RMB 100 Million Yuan. Source of data: The same as Table 1. Insurance penetration and Securitization degree are calculated by the given data.

Table 7. Financial contribution of Guangzhou.

\begin{tabular}{ccccccccc}
\hline & 2008 & 2009 & 2010 & 2011 & 2012 & 2013 & 2014 \\
\hline GDP & 8287.38 & 9138.21 & $10,748.28$ & $12,423.44$ & $13,551.21$ & $15,420.14$ & $16,706.87$ \\
Value added of the tertiary industry & 4890.33 & 5560.77 & 6557.45 & 7641.92 & 8616.79 & 9964.34 & 9998.68 \\
Value added of financial intermediation & 446.27 & 551.45 & 670.53 & 855.53 & 971.27 & 1141.93 & 1422.15 \\
Financial contribution to tertiary industry & 9.13 & 9.92 & 10.23 & 11.20 & 11.27 & 11.46 & 14.22 \\
Financial contribution to GDP & 5.38 & 6.03 & 6.23 & 6.89 & 7.17 & 7.41 & 8.51 \\
\hline
\end{tabular}

Source of data: http://www.gzstats.gov.cn/. Financial contribution to tertiary industry and financial contribution to GDP are calculated by the given data. 


\subsection{Opportunities}

\subsubsection{Policy Support}

Guangzhou government has issued the "Regional Financial Center Construction Plan of Guangzhou (20112020)”, planning to build up a regional financial center by 2025. Then more relevant policies are introduced by different departments. Obviously, construction of a regional financial center in Guangzhou has received strong political support. Moreover, the first special financial policy approved by the State Council for Guangzhou, called the "Nansha Financial 15" for short, clearly supports the development of Nansha District technology finance and shipping finance, promotes finance cooperation between Guangdong, Hong Kong, Macao and Taiwan, and improves the comprehensive financial services system to explore the experience of RMB capital item's exchange. Great impetus will be added to the process of regional financial center construction along with the in-depth financial cooperation of Guangdong and Hong Kong, Macao and Taiwan.

\subsubsection{Internet Finance Creates Opportunity}

Under China's New Normal economic environment, the Internet finance will create an important opportunity for Guangzhou to achieve great-leap-forward development. At present, Guangzhou has set up more than 150 Internet enterprises, including Escrow, P2P Online Lending and Crowdfunding. In addition, the Guangzhou Folk Financial Street, the Central Business District, Guangzhou Financial Service District for medium-sized, small and micro businesses and Haizhu Maxell Square have been selected to be the Internet Financial Industry Base. The rapid development of Internet finance in Guangzhou suggests that the study and implement of strategy for "finance+" program as well as introduce a great number of large Internet finance enterprises into Guangzhou may create new growth point for the regional financial center.

\subsection{Threats}

During the process of constructing a regional financial center, Guangzhou is under threats mainly from other domestic regional financial centers. There are already 30 cities across the country that proposed the target of building up the financial centers. For example, Shenyang plans to build up a financial center in Northeast China by making use of the Old Industrial Base in Northeast China and industrial finance. Tianjin wants to transform the strong momentum of economic development and the rapid tendency of financial agglomeration into action to build a financial center of North China. Jinan and Qingdao are striving to construct a financial center in the Yellow River region. Moreover, Nanjing, Hangzhou, Chengdu and Chongqing, Wuhan, Xi'an and Lanzhou, Xiamen, the cities mentioned above strive to build up a regional financial center in its own region. Nowadays, the construction of CBD prevails throughout the nation. Meanwhile, the policies to attract and retain high-quality enterprises or high-end financial talents are put forward constantly. Therefore, Guangzhou still has a long way to go in the battle that fights for financial resources.

\section{Conclusions and Recommendations}

This paper uses principal component analysis methodology to evaluate competition of six regional financial centers including Guangzhou. And the composite scores show that Guangzhou is ranked the fourth. The SWOT analysis of Guangzhou regional financial center is then adopted and the results argue that it is possible and necessary for Guangzhou to build up a regional financial center, but some issues exist during the construction process. Based on the above analysis, four recommendations to improve Guangzhou's financial center are put forward.

Firstly, the headquarters' economy environment should be improved. In order to attract more headquarters and financial institutions at home and abroad as well as to achieve recessive effect, measures should be taken with respect to six aspects, including basic conditions, business facility, research capability, professional service, government service and opening up, to create an attractive business environment.

Secondly, the financial system should be perfected and financial innovation should be promoted. It's wise for Guangzhou to strengthen the professional communication with financial developed countries. Therefore, we can learn and then make use of the successful experiences from abroad about financial innovation in some aspects, such as mechanics innovation, product innovation and service innovation. Moreover, it is necessary for Guangzhou to promote the organic integration of credit market, capital market and insurance market. To be specific, we should promote the joint-stock reform of rural credit cooperatives and speed up the restructure of commer- 
cial bank in Guangzhou. As a result, the optimization of the financial system will drive the city to attract more investments. In addition, from the perspective of the customer, it is quite important to design diversified financial products and provide personalized financial services to meet customers' different demands like lending for house, car, travel or education. With the rapid development of Internet finance, the financial institutions need to follow the trend and provide products and services to meet the users' experience and enhance the adhesiveness of users. In a word, financial innovation is the only way for Guangzhou to improve its financial development.

Thirdly, the cooperation with Shenzhen, Hong Kong and Macao should be strengthened. Guangzhou and Shenzhen have been in competition states during the process of building up regional financial centers, which may do harm to both sides. Guangzhou and Shenzhen are two developed cities with higher level of financial development in Southern China, thus we support the conception of establishing a "Dual-core Regional Financial Center" for the two cities. The financial cooperation platform will provide opportunities for Shenzhen to make use of land resources in Guangdong Province, while Guangzhou can take advantage of Shenzhen's financial development. In addition, Guangzhou should seize the opportunity of “Guangdong-Hong Kong-Macau FTZ”, expanding the economic hinterland and enhancing economic radiation effect through the cooperation with Shenzhen, Hong Kong and Macao.

Finally, emphasis should be placed on personnel training and research and development. A superior talent training mechanism and research infrastructure should be created to cultivate innovative talents for Guangzhou. Equity, options and other financial incentives should be included into the reward mechanism to encourage employees to innovate.

\section{References}

[1] Kindleberger, C.P. (1974) The Formation of Financial Centers: A Study in Comparative Economic History. Princeton University Press, New Jersey.

[2] Thrift, N. (1994) On the Social and Cultural Determinants of International Financial Centers: the Case of the City of London. Blackwell, Oxford.

[3] Porteous, D.J. (1995) The Geography of Finance: Spatial Dimensions of Intermediary Behavior. Avebury.

[4] Hew, D. (2002) Singapore as a Regional Financial Center. AT10 Research Conference, No. 3, 7-8.

[5] Wang, R.X. and Shi, D. (2005) Advantages, Disadvantages and Recommendations for Constructing a Regional Financial Center. Journal of Wuhan Finance Monthly, No. 6.

[6] Xie, T.F. (2008) Spatial Integration for Finance Resources: Mode Selection of the Formation of Beijing Financial Center. Journal of Capital University of Economics and Business, No. 06, 90-94.

[7] Reed, H.C. (1981) The Pre-Eminence of International Financial Centers. Praeger, New York.

[8] Richard, M.G., Malloy, M. and Kazanas, K. (1990) What Makes a Financial Center? Financial Services, Financial Centers: Public Policy and the Competition for Markets, Firms, and Jobs, Boulder. Westview Press, Colorado.

[9] Zhou, L.Q. and Pan, H.S. (2003) Comparative Study about the Competitiveness of Domestic Urban Financial System: A Case of Tianjin. Journal of Tianjin Social Sciences, 11, 93-98.

[10] Sun, J. and Miao, J.J. (2006) Division and Formation for the Regional Financial Center of China. Journal of Modern Economic Research, No. 2.

[11] Xie, F.Y. (2013) A Study about the Formation of the Regional Financial Center in Henan Province. Henan University.

[12] Lu, L. (2009) Regional Financial Center Model in China: Market Select and Financial Innovation, Discussing the Layout of Guangzhou-Shenzhen Financial Center. Journal of South China Finance, No. 6.

[13] Shao, X.Y. and Zhu, Z.Y. (2010) Conception of Building a Dual-Core Regional Financial Center for Guangzhou and Shenzhen. Journal of South China Finance, No. 2.

[14] Lu, M.F. and Pan, X.H. (2010) Questions and Countermeasures about the Construction of the Regional Financial Centers in China. Journal of Qinghai Finance, No. 04, 9-12.

[15] Tao, Y. (2011) A Study about the Development of the Regional Financial Center in China. Journal of China Business and Market, No. 08, 84-88.

[16] Chen, Y. and Zhu, Y.Z. (2011) The Mode and Path for the Construction of a Regional Financial Center in Western China. Journal of Social Sciences Review, 11, 34-36.

[17] Li, J.C. and Zhou, Q.Q. (2013) A Study of the Coordinated Development of the Regional Financial Center of Guangzhou and Shenzhen. Journal of Industrial \& Science Tribune, 18, 123-124.

[18] Wang, Z.Q. and Sun, G. (2003) The Empirical Analysis on the Relationship of Financial Development Scale, Structure, Efficiency and Economic Growth. Journal of Management World, No. 7, 13-20. 